\title{
Age-Dependent and Selective Impairment of Long-Term Potentiation in the Anterior Piriform Cortex of Mice Lacking the Fragile X Mental Retardation Protein
}

\author{
John Larson, Ruth E. Jessen, Daniel Kim, Ananda-Kriiya S. Fine, and Johann du Hoffmann \\ Psychiatric Institute, Department of Psychiatry, College of Medicine, University of Illinois, Chicago, Illinois 60612
}

\begin{abstract}
Synaptic function and plasticity were studied in mice lacking the fragile $\mathrm{X}$ mental retardation protein (FMRP), a model for the fragile $\mathrm{X}$ mental retardation syndrome. Associational connections were studied in slices of anterior piriform (olfactory) cortex, and Schaffercommissural synapses were studied in slices of hippocampus. Knock-out (KO) mice lacking FMRP were compared with congenic C57BL/6J wild-type (WT) controls. Input- output curves and paired-pulse plasticity were not significantly altered in KO compared with WT mice in either the olfactory cortex or hippocampus. Long-term potentiation (LTP) induced by theta burst stimulation in the anterior piriform cortex was normal in KO mice aged $<6$ months but was impaired in KO mice aged $>6$ months. The deficit in LTP was significant in mice aged 6-12 months and more pronounced in mice aged 12-18 months. Similar differences between WT and K0 mice were seen whether LTP was induced in the presence or absence of a $\mathrm{GABA}_{\mathrm{A}}$ receptor blocker. Postsynaptic responses to patterned burst stimulation in KO mice showing impaired LTP were not significantly different from those in WT mice, suggesting that the LTP deficit was not caused by alterations in circuit properties. No differences in hippocampal LTP were observed in WT and KO mice at any ages. The results indicate that FMRP deficiency is associated with an age-dependent and region-selective impairment in long-term synaptic plasticity.
\end{abstract}

Key words: fragile X syndrome; FMRP; LTP; synaptic plasticity; olfactory cortex; hippocampus

\section{Introduction}

Fragile X syndrome (FXS) is the most common inherited cause of human mental retardation. Affected individuals exhibit moderate-to-severe mental retardation and developmental delays as well as characteristic physical features including macroorchidism and facial abnormalities (Schapiro et al., 1995). FXS is also commonly accompanied by neuropsychiatric problems such as hyperactivity, autism, attention disorders, and seizures (de Vries et al., 1998). The syndrome is most often caused by a trinucleotide (CGG) repeat expansion in the fragile X mental retardation 1 (FMR1) gene, leading to DNA methylation and transcriptional silencing; other mutations involving the FMR1 gene can cause FXS if they prevent production or alter functional domains of the encoded protein, the fragile $\mathrm{X}$ mental retardation protein (FMRP) (O'Donnell and Warren, 2002). The function of FMRP is not entirely understood. In brain, the protein is found in neurons and is transported into dendrites (Devys et al., 1993; Feng et al., 1997). Because FXS patients show dendritic spine abnormalities in the cerebral cortex (Irwin et al., 2001), it appears that FMRP plays an important role in spine maturation or plasticity (Bagni and Greenough, 2005). FMRP has been characterized as

Received June 27, 2005; revised Aug. 10, 2005; accepted Sept. 3, 2005.

This work was supported by grants from the National Institutes of Health (DC005793) and the Fragile X Research Foundation.

Correspondence should be addressed to Dr. John Larson, Psychiatric Institute (M/C 912), University of Illinois at Chicago, 1601 West Taylor Street, Chicago, IL 60612. E-mail: jrlarson@uic.edu.

DOI:10.1523/JNEUROSCI.2638-05.2005

Copyright $\odot 2005$ Society for Neuroscience $\quad$ 0270-6474/05/259460-10\$15.00/0 an RNA-binding protein that may be involved in transport and localization of a subset of neuronal mRNAs as well as regulating their translation (O'Donnell and Warren, 2002; Willemsen et al., 2004; Bagni and Greenough, 2005).

Mice with targeted mutations (knock-outs) of the Fmrl gene (Fmr1 KO mice) have been developed as models for FXS (Bakker et al., 1994). Fmr1 KO mice exhibit hyperactivity in open field tests, heightened seizure susceptibility, exaggerated responses to sensory stimulation, normal fear conditioning, and mild impairments in spatial learning tasks (Kooy, 2003). The mice also exhibit cortical spine abnormalities similar to FXS patients (Comery et al., 1997; Nimchinsky et al., 2001; Irwin et al., 2002; Galvez and Greenough, 2005). However, excitatory synapses in field CA1 of hippocampus of Fmr1 KO mice were found to exhibit normal long-term potentiation (LTP), a learning-related form of synaptic plasticity involving spine shape changes (Godfraind et al., 1996; Paradee et al., 1999). On the other hand, Li and colleagues (2002) found that synaptic potentials recorded in layer IV/V of frontal neocortex in response to white matter stimulation showed greatly diminished LTP in Fmr1 KO mice.

These findings prompted us to examine LTP in the primary olfactory (piriform) cortex. The structure of the piriform cortex simplifies interpretation of synaptic field potentials, and synapses in this region exhibit LTP that is phenomenologically similar, but not identical, to hippocampal LTP (Jung et al., 1990a; Kanter and Haberly, 1990,1993; Collins, 1994; Jung and Larson, 1994). We find that LTP of monosynaptic responses evoked by selective stimulation of excitatory associational fibers is substantially re- 
A

WT

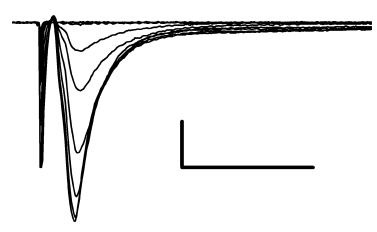

C

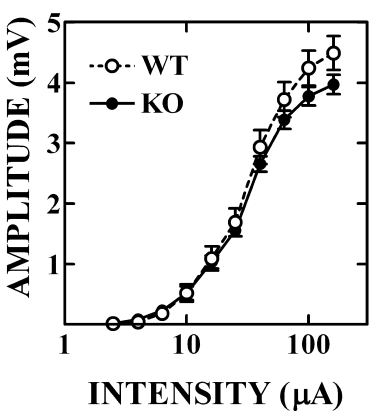

KO

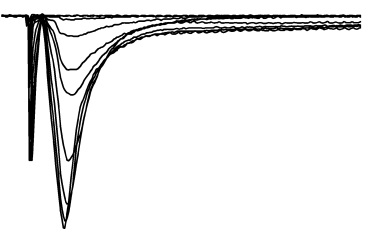

6-12 MONTHS

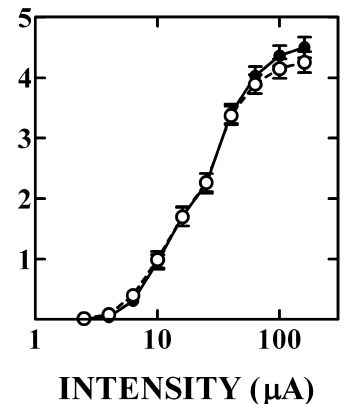

B

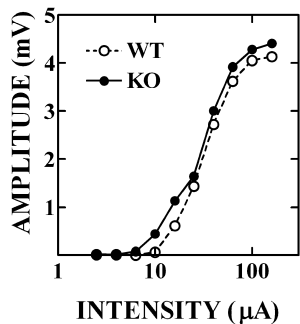

12-18 MONTHS

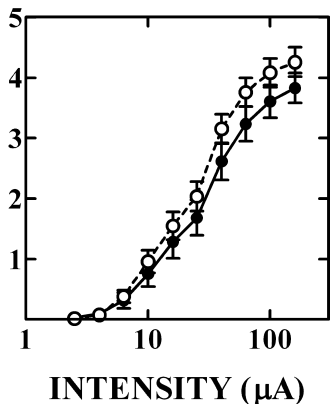

Figure 1. Synaptic input- output curves in Fmr1 KO and WT mice at three age ranges. A, Field EPSPs evoked by $10-160 \mu \mathrm{A}$ ASSN fiber stimulation in typical slices from a WT (5.5-month-old) and an Fmr1 KO (3-month-old) mouse. Each record is an average of four consecutive responses. Stimulus intensities were $2.5,4.0,6.3,10.0,16.0,25.0,40.0,63.0,100.0$, and 160.0 $\mu$ A. Calibration: $1 \mathrm{mV}, 10 \mathrm{~ms}$. $\boldsymbol{B}$, Input- output curves relating stimulus intensity and field EPSP amplitude in the WT (open circles) and KO (filled circles) slices shown in $\boldsymbol{A}$. Note the logarithmic scale on abscissa. $\boldsymbol{C}$, Input-output curves for WT and KO mice for indicated age groups. Data are means \pm SEM for 11-25 mice per group.

A
WT

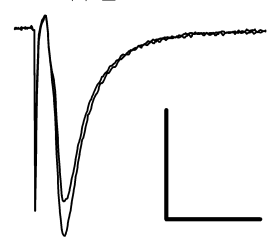

KO

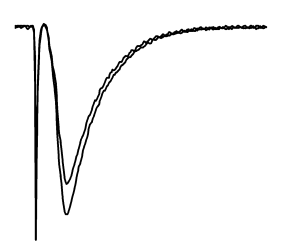

B

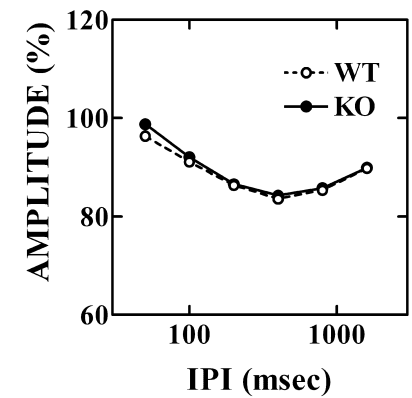

C

3-6 MONTHS

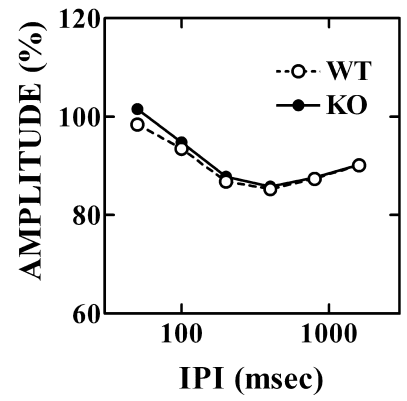

6-12 MONTHS

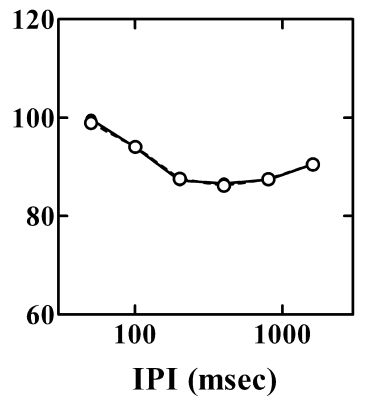

12-18 MONTHS

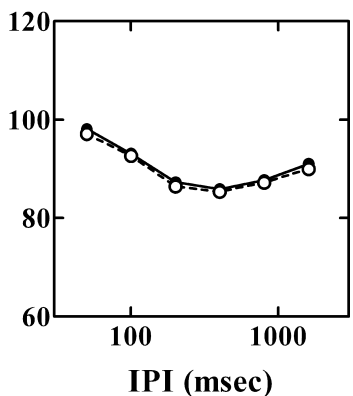

Figure 2. Paired-pulse depression of ASSN fiber responses in APC slices from WT and KO mice. $\boldsymbol{A}$, Records showing paired-pulse depression at $400 \mathrm{~ms} \mathrm{IPI} \mathrm{in} \mathrm{slices} \mathrm{from} \mathrm{representative} \mathrm{WT} \mathrm{(5.5-month-old)} \mathrm{and} \mathrm{KO} \mathrm{(5-month-old)} \mathrm{mice.} \mathrm{Each} \mathrm{record} \mathrm{is} \mathrm{an} \mathrm{average}$ of four consecutive responses. Smaller trace in each pair is the second response to the paired-pulse stimulation. Calibration: $1 \mathrm{mV}$, $10 \mathrm{~ms}$. $\boldsymbol{B}$, Paired-pulse curves showing relationship between IPI and synaptic depression in the WT and K0 slices shown in $\boldsymbol{A}$. Calibration: $1 \mathrm{mV}, 10 \mathrm{~ms}$. C, Paired-pulse curves for WT and K0 slices at indicated age ranges. Data are means \pm SEM for 11-25 mice per group. duced in slices of anterior piriform cortex (APC) from Fmr1 KO mice, compared with wild-type (WT) controls. This impairment of LTP in the piriform cortex is age dependent, appearing only in mice at least 6 months of age, and selective, because it is not observed in the CA1 field of hippocampus. These results suggest that deficits in cortical LTP mechanisms may contribute to cognitive impairments in FXS.

\section{Materials and Methods}

Animals. Male Fmr1 KO and WT mice were bred from congenic C57BL/6J stock obtained from The Jackson Laboratory (Bar Harbor, ME). The mutation had been back-crossed at least 10 generations into the C57BL/6 background. Experiments and analyses were both conducted blind with respect to genotype.

Slices of anterior piriform cortex. Slices of APC were prepared from adult mice (3-18 months of age) as described previously (Jung and Larson, 1994). Briefly, a block of the brain containing the APC was produced using coronal cuts through the plane of the caudal tail of the lateral olfactory tract (LOT) and a plane $2 \mathrm{~mm}$ rostral to that landmark. The piriform cortex was isolated with a cut tangential to the pial surface and sliced at $400 \mu \mathrm{m}$, perpendicular to the cortical surface and in a parasagittal plane (parallel to the LOT), on a tissue chopper. Slices were maintained in an interface chamber at $35^{\circ} \mathrm{C}$ and perfused constantly $(1.0 \mathrm{ml} / \mathrm{min})$ with artificial CSF containing the following (in $\mathrm{mm}$ ): $124 \mathrm{NaCl}, 3 \mathrm{KCl}, 1.2 \mathrm{KH}_{2} \mathrm{PO}_{4}, 26 \mathrm{NaHCO}_{3}, 2.5$ $\mathrm{MgSO}_{4}, 2.5 \mathrm{CaCl}_{2}, 2 \mathrm{Na}$-ascorbate, and 10 D-glucose, gassed with $95 \% \mathrm{O}_{2}$ and $5 \% \mathrm{CO}_{2}$.

Stimulation (bipolar, insulated stainlesssteel wires; diameter, $50 \mu \mathrm{m})$ and recording (glass micropipettes; $1-5 \mathrm{M} \Omega$; filled with $2 \mathrm{M}$ $\mathrm{NaCl}$ ) electrodes were placed in layer Ib to activate and monitor associational system (ASSN) synaptic field potentials. One stimulation electrode ( $\mathrm{S} 1$ ) was positioned rostral to the recording electrode and activated the ASSN fibers orthodromically; the other (S2) was placed caudal to the recording electrode and activated a separate population of ASSN synapses via antidromic activation of caudally directed fibers and orthodromic activation of feedback fibers. Laminar profiles and paired-pulse stimulation were used to distinguish between ASSN and LOT synapses as described previously (Bower and Haberly, 1986; Jung et al., 1990a,b) and to optimally position electrodes in each slice tested. All slices from each animal were tested before experiments, and one or two slices exhibiting the largest ASSN field potentials were selected for study. Electrophysiological signals were amplified $(500 \times)$, low-pass filtered (5 $\mathrm{kHz})$, digitized by microcomputer $(10 \mathrm{kHz})$, and analyzed on-line using custom software.

Input-output curves were constructed by varying stimulus intensity between 2.5 and 160 $\mu \mathrm{A}$ (pulse duration, $0.1 \mathrm{~ms}$ ) and measuring the peak amplitude of dendritic field EPSP (fEPSP) evoked. Four responses were collected at each 

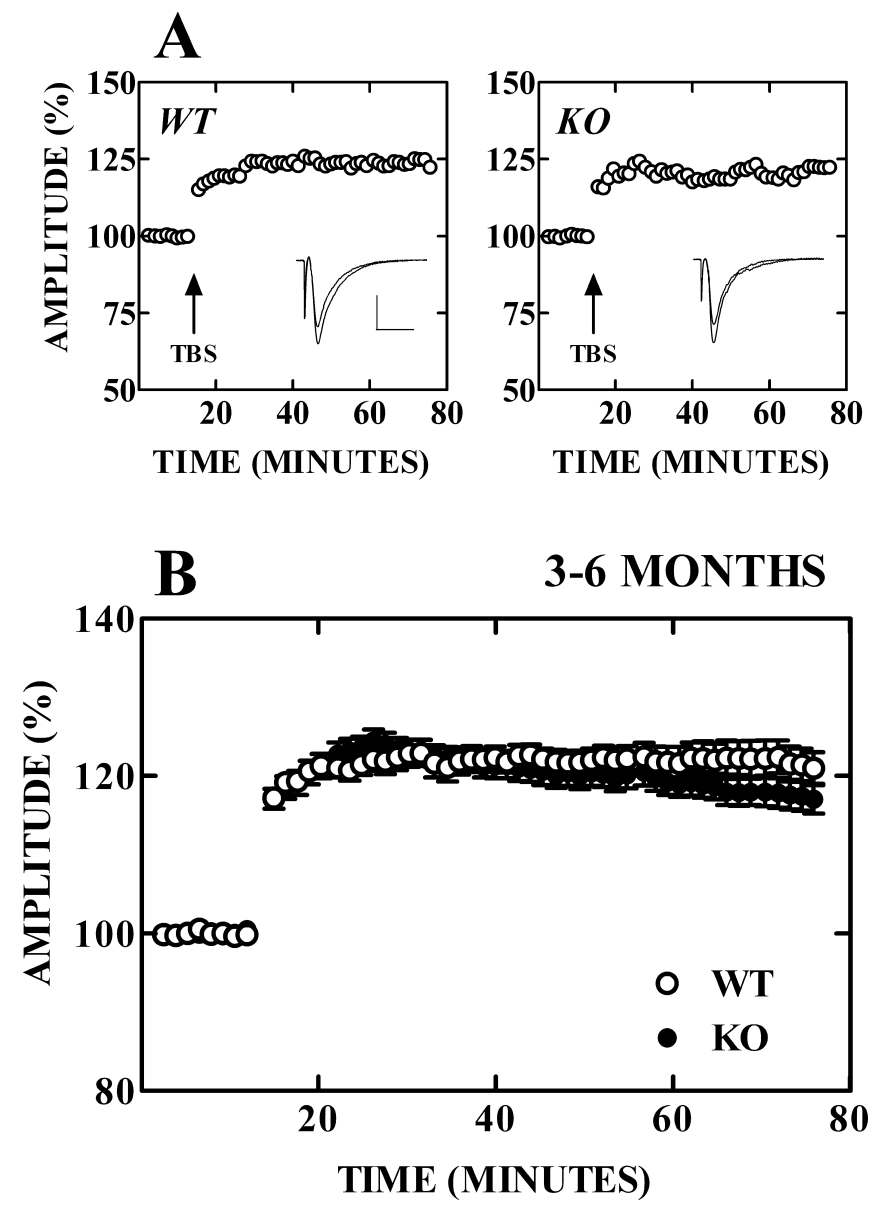

Figure 3. LTP in APC of picrotoxin-treated slices from 3- to 6-month-old WT and Fmr 1 KO mice. $A$, Plots of fEPSP amplitude over time before and after TBS (arrow) in slices from representative WT (3-month-old) and K0 (5.5-month-old) mice. Each circle is the average of four consecutive responses and is normalized to the average of the $10 \mathrm{~min}$ baseline period (100\%). The insets show records taken $1 \mathrm{~min}$ before and $60 \mathrm{~min}$ after TBS superimposed. Calibration: 1 $\mathrm{mV}, 10 \mathrm{~ms} . \boldsymbol{B}$, Average data (mean \pm SEM) obtained from $11 \mathrm{WT}$ (open circles) and $11 \mathrm{KO}$ (filled circles) mice.

intensity and averaged. Paired-pulse curves were determined by stimulating the synapses with twin pulses at interpulse intervals (IPIs) of 50$1600 \mathrm{~ms}$. Stimulus intensity was set to evoke a half-maximal fEPSP. The initial slope and peak amplitude of the response to the second (test) pulse were calculated as a percentage of those of the first (conditioning) pulse of each pair. In one set of experiments, LTP was induced after perfusing slices with picrotoxin $\left(10 \mu \mathrm{M}\right.$; RBI, Natick, MA) to block $\mathrm{GABA}_{\mathrm{A}}$ receptor-dependent synaptic inhibition (Kanter and Haberly, 1993). Baseline stimulus intensity was set to evoke a half-maximal fEPSP. Theta burst stimulation (TBS) (Larson et al., 1986) was used to induce "associative" LTP. In the TBS protocol, both pathways were activated simultaneously with 10 high-frequency bursts $(100 \mathrm{~Hz}$; four pulses) repeated at $200 \mathrm{~ms}$ intervals $(5 \mathrm{~Hz})$. During TBS, the stimulus duration was doubled to $0.2 \mathrm{~ms}$. fEPSPs were monitored on the two pathways alternately at $10 \mathrm{~s}$ intervals for at least $10 \mathrm{~min}$ before and at least $60 \mathrm{~min}$ after TBS. Slices that did not exhibit stable fEPSPs during the baseline period were excluded from study. fEPSP amplitude was measured rather than initial slope, because the former was less variable than the latter in APC slices. The degree of potentiation induced by TBS was calculated as the percentage increase at each time point after patterned stimulation, relative to the baseline average. Responses during patterned burst stimulation were quantified by measuring the area of negativity underlying the response to the four stimuli in the burst, as described previously (Larson and Lynch, 1988; Larson et al., 1999).

In a second set of LTP experiments, slices were not treated with picro-
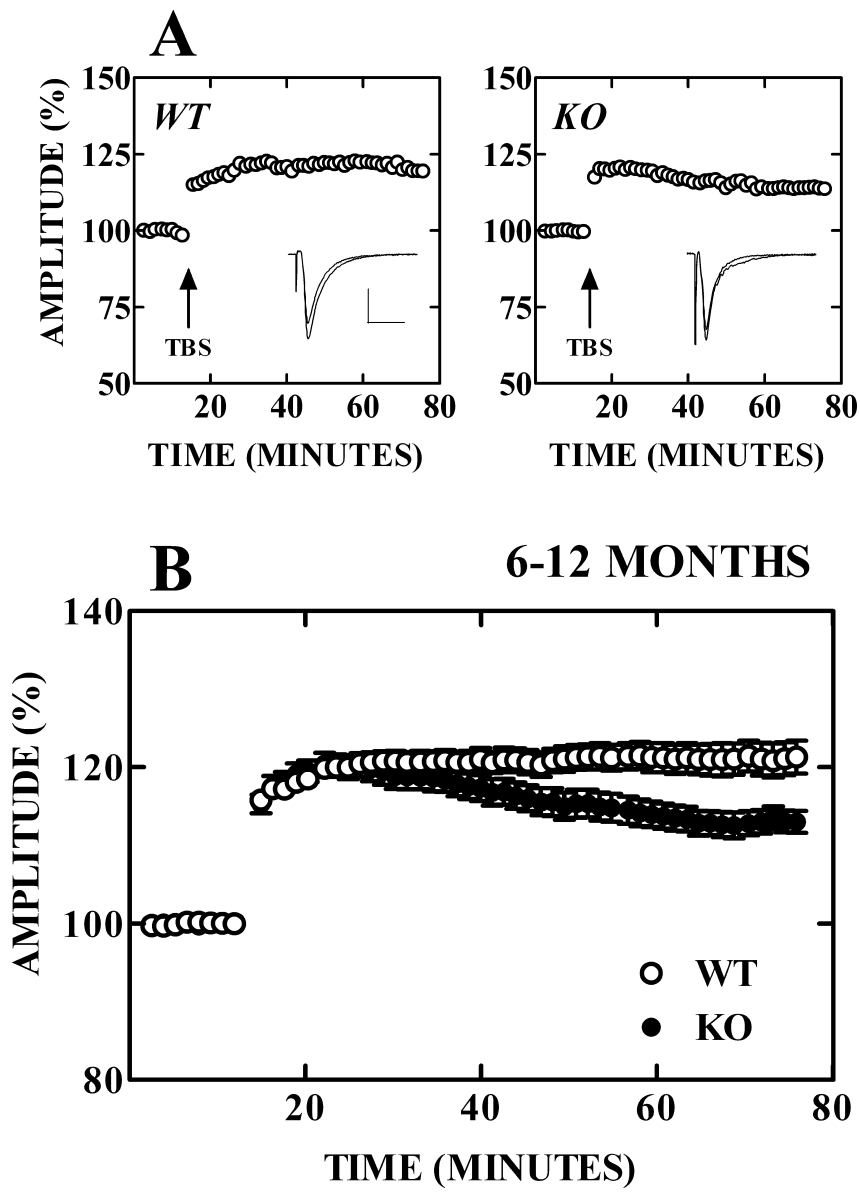

Figure 4. LTP in the APC of picrotoxin-treated slices from 6- to 12-month-old WT and Fmr1 KO mice. A, Plots of fEPSP amplitude over time before and after TBS (arrow) in slices from representative WT (12-month-old) and KO (11-month-old) mice. Each circle is the average of four consecutive responses and is normalized to the average of the $10 \mathrm{~min}$ baseline period (100\%). The insets show records taken $1 \mathrm{~min}$ before and $60 \mathrm{~min}$ after TBS superimposed. Calibration: $1 \mathrm{mV}, 10 \mathrm{~ms}$. B, Average data (mean \pm SEM) obtained from 14 WT (open circles) and $15 \mathrm{KO}$ (filled circles) mice.

toxin. Otherwise, the procedures used to induce and assess LTP were identical to those of the experiments described above.

Slices of hippocampus. Hippocampal slices from $\mathrm{KO}$ and WT mice aged 3-12 months were prepared and maintained using methods described previously (Larson et al., 1999). Hippocampi were dissected free, and slices were cut at $400 \mu \mathrm{m}$ transverse to the long axis of the hippocampus and maintained as described for piriform slices above.

Stimulation and recording electrodes were placed in stratum radiatum of field CA1 to activate and monitor Schaffer-commissural (SC) fiberevoked synaptic field potentials. One stimulation electrode (S1) was positioned in CA1c to activate the SC fibers in the orthodromic sense, and the other (S2) was placed in CAla to activate the fibers in the antidromic sense. Laminar profiles were used to place electrodes optimally in each slice tested. All slices from each animal were tested before experiments, and one or two slices exhibiting the largest field potentials were selected for study.

Input-output curves were constructed using stimulus intensities from 2.5-63 $\mu \mathrm{A}$. When a population spike appeared, the response to the highest-intensity stimulus not evoking a population spike was taken as the maximal field EPSP, and that value was used for the response to all higher intensities. Paired-pulse curves were determined in the same manner as for the piriform slices. In LTP experiments, the two stimulation pathways (S1 and S2) were used independently. In most LTP experiments, one pathway was given TBS consisting of five theta bursts, and the other was given TBS consisting of 10 theta bursts. The two induction 

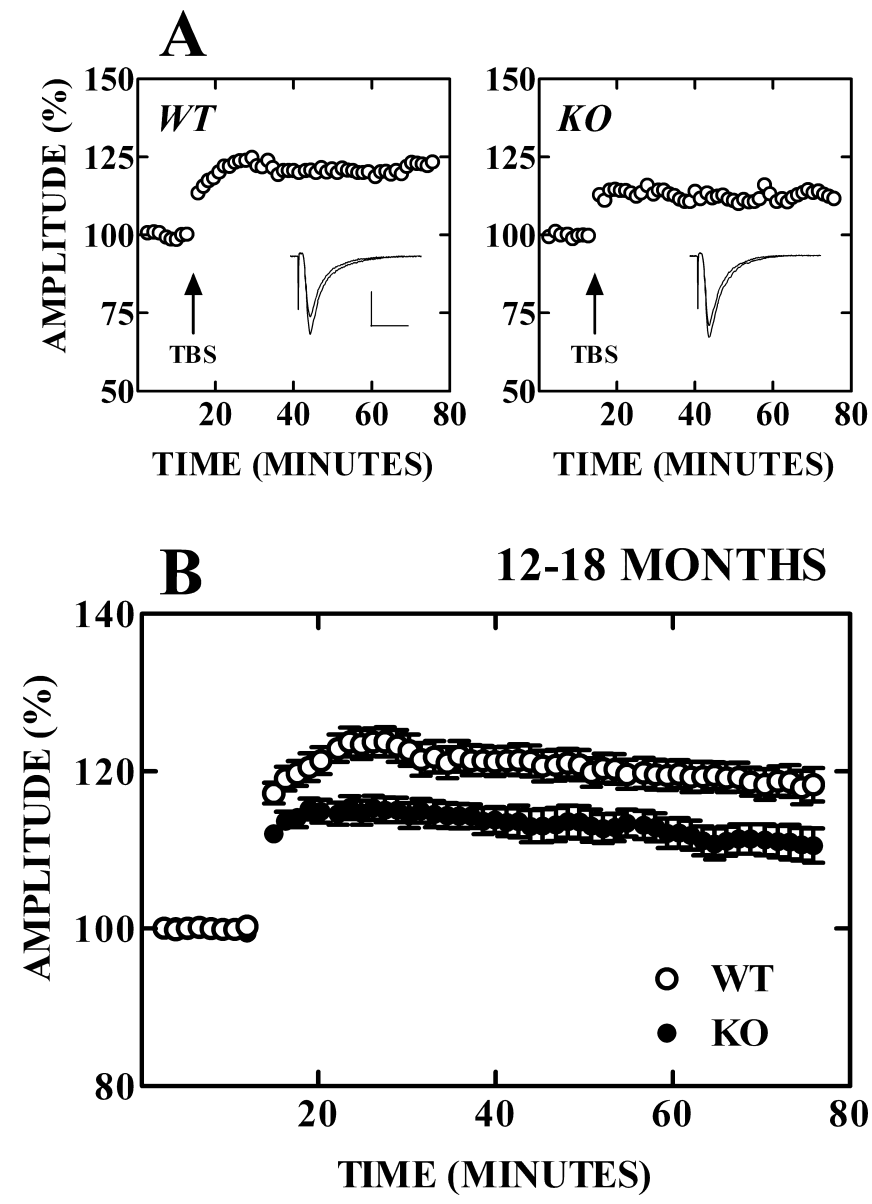

Figure 5. LTP in the APC of picrotoxin-treated slices from 12-to 18-month-old WT and Fmr1 KO mice. $\boldsymbol{A}$, Plots of fEPSP amplitude over time before and after TBS (arrow) in slices from representative WT (15.5-month-old) and KO (15.5-month-old) mice. Each circle is the average of four consecutive responses and is normalized to the average of the $10 \mathrm{~min}$ baseline period (100\%). The insets show records taken $1 \mathrm{~min}$ before and $60 \mathrm{~min}$ after TBS superimposed. Calibration: $1 \mathrm{mV}, 10 \mathrm{~ms} . \boldsymbol{B}$, Average data (mean \pm SEM) obtained from 10 WT (open circles) and $10 \mathrm{KO}$ (filled circles) mice.

events were separated by at least $30 \mathrm{~min}$. In some experiments, only one pathway was given TBS. In all cases, during TBS, the stimulus duration was doubled to $0.2 \mathrm{~ms}$. fEPSPs were monitored on the two pathways alternately at $10 \mathrm{~s}$ intervals for at least $10 \mathrm{~min}$ before and at least $60 \mathrm{~min}$ after TBS. The degree of potentiation induced by TBS and the response to patterned burst stimulation were calculated in the same way described for the piriform experiments, except that the measurements of LTP magnitude were based on the initial slope of the fEPSP.

\section{Results}

Anterior olfactory cortex

All of the slices obtained from each animal were examined electrophysiologically, and the slice yielding the largest field EPSPs evoked by ASSN fiber stimulation was selected for detailed study. Because it became apparent that differences between Fmr1 KO and WT mice were age dependent, the results will be presented with mice separated into three age groups: mice $<6$ months of age, those between 6 and 12 months of age, and animals $>12$ months of age.

Input-output curves and paired-pulse plasticity Input-output curves were analyzed only for the pathway activated by the rostral stimulation electrode (S1), because it usually produced the larger response. Responses to single-pulse stimula- tion and the effects of increasing stimulus intensity were comparable in slices from WT and Fmrl KO mice (Fig. 1). For the entire range of the input-output curve, statistical analysis indicated no significant main effect of genotype on EPSP amplitude at any age (3-6 months of age, ANOVA, $F_{(1,23)}=1.21, p>0.2 ; 6-12$ months of age, $F_{(1,40)}=0.09, p>0.7 ; 12-18$ months of age, $\left.F_{(1,28)}=1.32, p>0.2\right)$. There were also no significant interactions between genotype and stimulus intensity on EPSP amplitude (3-6 months of age, $F_{(9,207)}=1.50, p>0.1 ; 6-12$ months of age, $F_{(9,360)}=0.68, p>0.7 ; 12-18$ months of age, $F_{(9,252)}=1.29$, $p>0.2$ ). The maximal field EPSP that could be evoked was unaffected by genotype $\left(F_{(1,91)}=1.95 ; p>0.1\right)$ or age $\left(F_{(2,91)}=\right.$ $1.29 ; p>0.2)$; there was no interaction between the two variables $\left(F_{(2,91)}=1.76 ; p>0.1\right)$.

Associational synapses in the anterior piriform cortex exhibit synaptic depression in response to paired stimulation. The degree of depression is minimal at very short (50 ms) IPIs, maximal at 200-800 ms, and recovers within a few seconds. Paired-pulse depression was very similar in slices from WT and Fmr1 KO mice in all age groups (Fig. 2). In the youngest age group only, there was a small, but significant, difference between WT and KO slices in paired-pulse responses. There was no main effect of genotype $\left(F_{(1,23)}=1.70 ; p>0.2\right)$, but there was an interaction between genotype and interpulse interval $\left(F_{(5,115)}=2.54 ; p<0.05\right)$. Second pulse responses were significantly larger in the $\mathrm{KO}$ slices at 50 ms IPI than in the WT slices (Newman-Keuls test; $p<0.01$ ). However, it should be noted that the absolute magnitude of this difference was only $\sim 3 \%$, and neither the WT or KO values were significantly different from $100 \%$ (one-sample $t$ tests; $p>0.05$ ). In the other age groups, there were no significant main effects of genotype on paired-pulse response $(6-12$ months of age, $F_{(1,40)}=1.63, p>0.7 ; 12-18$ months of age, $F_{(1,28)}=0.96, p>$ $0.9)$ nor interactions between genotype and IPI on paired-pulse response $\left(6-12\right.$ months of age, $F_{(5,200)}=0.64, p>0.6 ; 12-18$ months of age, $\left.F_{(5,140)}=0.25, p>0.9\right)$.

\section{LTP induced by TBS in picrotoxin-treated slices}

The first set of LTP experiments were conducted on slices continuously perfused with picrotoxin $(10 \mu \mathrm{M})$ to block $\mathrm{GABA}_{\mathrm{A}}$ receptor-dependent inhibition. A TBS protocol was used to induce LTP. As described previously (Jung et al., 1990a), TBS of ASSN fibers induces an initial potentiation that increases in magnitude for 10-15 min after TBS and then stabilizes. Typical and average results for slices from KO and WT mice aged $<6$ months are shown in Figure 3. The data were analyzed statistically using ANOVA on the percentage increase at $1,15,30$, and 60 min after TBS. There was no significant main effect of genotype $\left(F_{(1,20)}=\right.$ $0.61 ; p>0.4)$. There was a significant effect of time after TBS $\left(F_{(3,60)}=11.11 ; p<0.0001\right)$. The interaction between genotype and time after TBS was not significant, although it did approach significance $\left(F_{(3,60)}=2.60 ; p=0.06\right)$ as a result of a trend in the KO slices to decay over the hour after TBS.

In slices from mice aged 6-12 months, there was a clear difference in LTP between the WT and KO mice (Fig. 4). Potentiation immediately after TBS and during the 10 min growth period was similar in both groups, but the potentiation decayed thereafter in the KO slices, whereas it remained stable in the WT slices. ANOVA indicated no significant main effect of genotype on potentiation $\left(F_{(1,27)}=1.68 ; p>0.2\right)$. However, both the main effect of time after TBS $\left(F_{(3,81)}=6.98 ; p<0.001\right)$ and the interaction between genotype and time $\left(F_{(3,81)}=11.11 ; p<0.001\right)$ were significant. Multiple comparisons tests indicated that the poten- 
tiation was significantly smaller in $\mathrm{KO}$ than in WT slices 60 min after TBS (Newman-Keuls test; $p<0.01)$.

In slices from animals $>12$ months of age, the reduction in LTP in KO slices was present throughout the post-TBS recording period (Fig. 5). ANOVA showed significant main effects of both genotype $\left(F_{(1,18)}=7.77 ; p<0.05\right)$ and time after TBS $\left(F_{(3,54)}=4.06 ; p<0.05\right)$ on the magnitude of potentiation but no significant interaction $\left(F_{(3,54)}=0.64 ; p>0.5\right)$. Potentiation was significantly greater in WT slices than in KO slices at all time points after TBS (Newman-Keuls tests; $p<0.05$ at $1 \mathrm{~min}$ and $p<0.01$ at 15,30, and $60 \mathrm{~min}$ after TBS).

These results indicate that the differences in LTP in APC slices from WT and Fmr1 KO mice are age dependent. The LTP data collected from slices of WT mice at the three age ranges were subjected to ANOVA with age and time after TBS as factors. A similar analysis was conducted on the data obtained from slices from $\mathrm{KO}$ mice. For the WT mice, there was no significant main effect of age on potentiation $\left(F_{(2,32)}=0.63 ; p>0.5\right)$, there was a significant main effect of time after TBS $\left(F_{(3,96)}=11.42 ; p<0.0001\right)$, but there was no interaction between age and time after TBS $\left(F_{(6,96)}=0.71 ; p>0.6\right)$. On the other hand, for KO mice, there were significant main effects of both age $\left(F_{(2,33)}=4.01\right.$; $p<0.05)$ and time after TBS $\left(F_{(3,99)}=\right.$ 15.42 ; $p<0.0001)$ but no interaction between age and time after TBS $\left(F_{(6,99)}=\right.$ $0.77 ; p>0.55)$. Thus, it appears that age does not influence LTP in APC of WT mice; LTP in Fmr1 KO mice is mostly unaffected in young mice (3-6 months of age), but stable LTP deteriorates in older $\mathrm{KO}$ animals.

\section{LTP induced by TBS in slices not}

treated with picrotoxin

A separate set of experiments was run with slices maintained in control medium with inhibition intact (no picrotoxin). One set of experiments used mice aged 3-6 months, and a second set used animals aged 6-12 months.

In slices from mice aged $<6$ months, there were no statistically significant differences between $\mathrm{KO}$ and WT mice in the degree of potentiation after TBS (Fig. $6 A, B)$. ANOVA indicated no main effect of genotype $\left(F_{(1,16)}=1.84 ; p>0.1\right)$, a significant effect of time after TBS $\left(F_{(3,48)}=5.25 ; p<0.01\right)$, and no interaction between genotype and time $\left(F_{(3,48)}=\right.$ $1.05 ; p>0.3)$.

In slices from animals aged 6-12
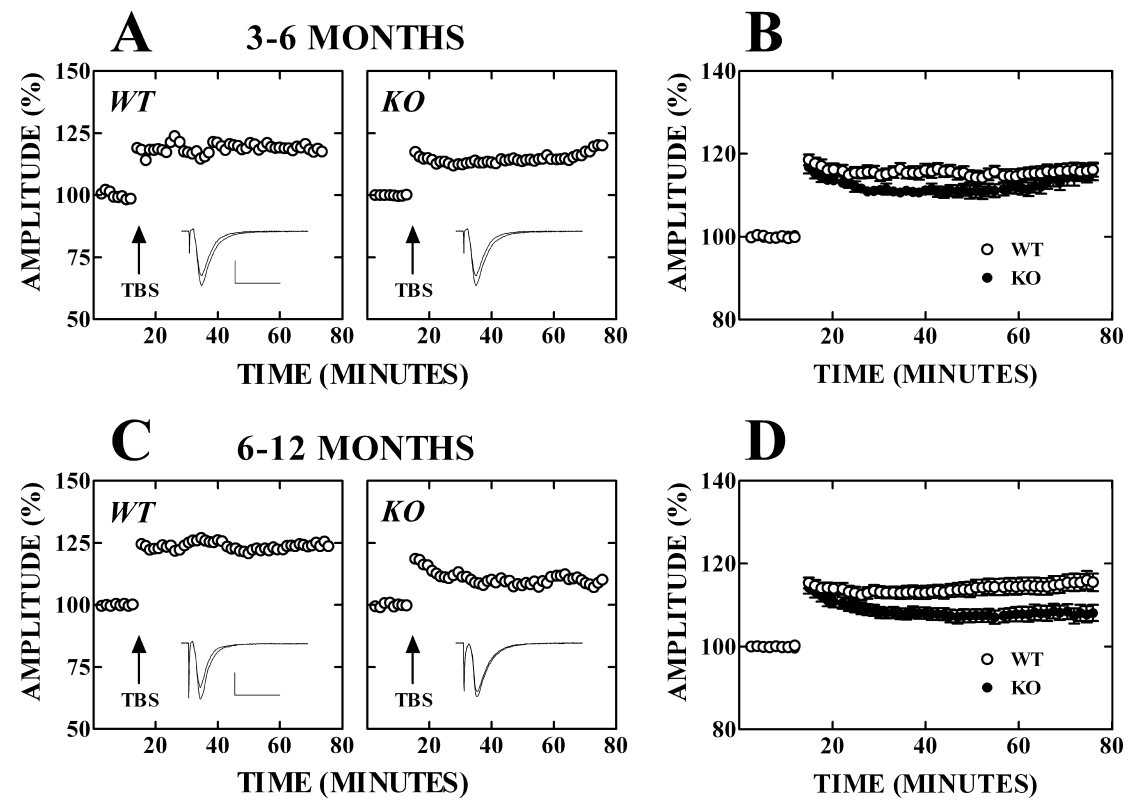

Figure 6. LTP in the APC of slices from WT and KO mice with GABAergic transmission intact. $A$, Plots of fEPSP amplitude over time before and after TBS (arrow) in slices from representative WT (4-month-old) and KO (4-month-old) mice. Each circle is the average of four consecutive responses and is normalized to the average of the $10 \mathrm{~min}$ baseline period (100\%). The insets show records taken $1 \mathrm{~min}$ before and $60 \mathrm{~min}$ after TBS superimposed. Calibration: $1 \mathrm{mV}, 10 \mathrm{~ms}$. B, Average data (mean \pm SEM) obtained from 10WT (open circles) and eight KO (filled circles) mice aged 3-6 months. C, Plots of fEPSP amplitude over time before and after TBS (arrow) in slices from representative WT (12-month-old) and KO (8.5-month-old) mice. Each circle is the average of four consecutive responses and is normalized to the average of the $10 \mathrm{~min}$ baseline period (100\%). The insets show records taken $1 \mathrm{~min}$ before and $60 \mathrm{~min}$ after TBS superimposed. Calibration: $1 \mathrm{mV}, 10 \mathrm{~ms}$. D, Average data (mean \pm SEM) obtained from $16 \mathrm{WT}$ (open circles) and $17 \mathrm{KO}$ (filled circles) mice aged $6-12$ months.
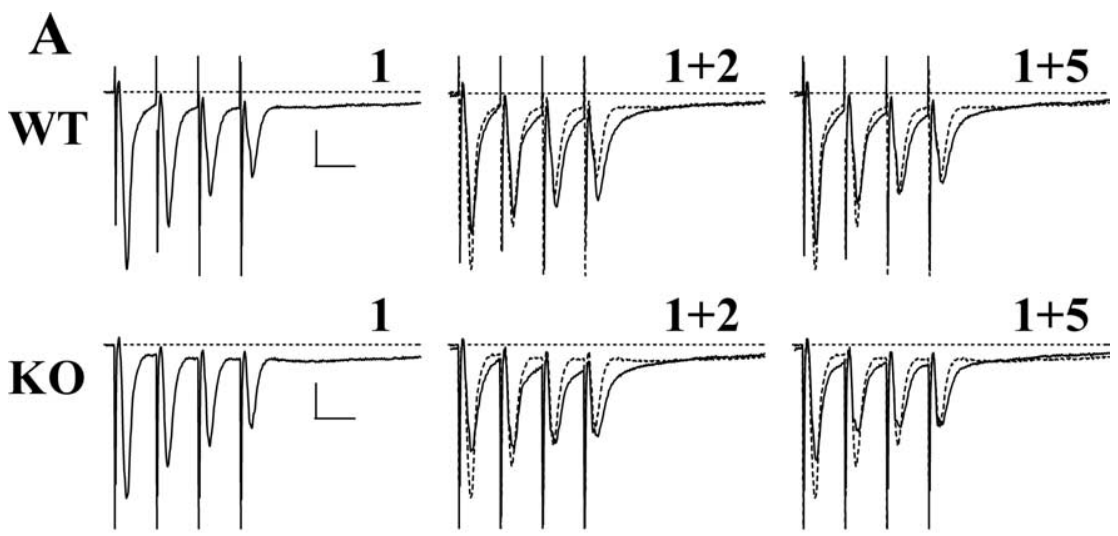

B

3-6 Мo. 6-12 Mo.

C

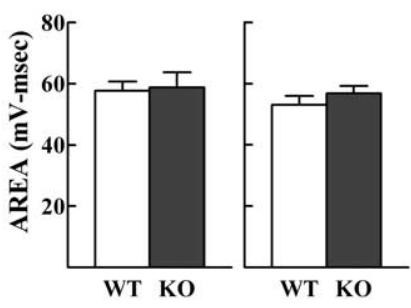

3-6 MONTHS

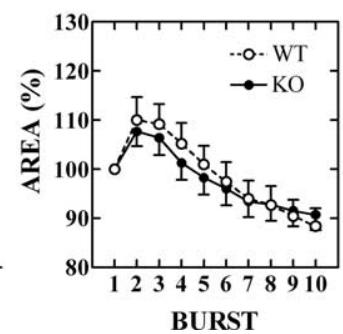

6-12 MONTHS

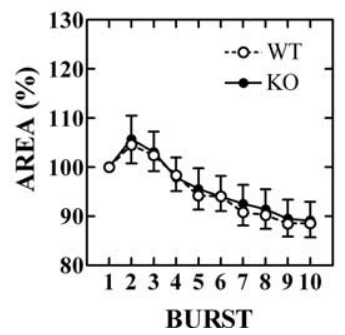

Figure 7. Burst responses in APC of slices from WT and KO mice with GABAergic transmission intact. $\boldsymbol{A}$, Recordings of burst response waveforms in representative WT (4.5-month-old) and KO (4-month-old) mice. Shown are responses to the first burst (1), first (dotted trace) and second superimposed $(1+2)$, and first (dotted trace) and fifth superimposed $(1+5)$. Calibration: $1 \mathrm{mV}$, $10 \mathrm{~ms}$. B, Area of negativity underlying the response to the first burst (mean + SEM) in slices from 11 WT and 11 KO mice aged 3-6 months and slices from $20 \mathrm{WT}$ and $18 \mathrm{KO}$ mice aged $6-12$ months. C, Burst response area normalized to the first burst response in the same slices in $\boldsymbol{B}$. Data are means \pm SEM. 
months, there was a clear difference between KO and WT mice in the response to TBS. As was seen in the experiments with picrotoxin, the potentiation in slices from older $\mathrm{KO}$ mice decayed over time, whereas potentiation in slices from WT mice remained stable throughout the recording period (Fig. 6C,D). ANOVA yielded a main genotype effect of borderline significance $\left(F_{(1,31)}=4.07 ; p=0.05\right)$, a significant main effect of time after TBS $\left(F_{(3,93)}=8.49 ; p<0.0001\right)$, and a significant interaction between genotype and time $\left(F_{(3,93)}=3.49 ; p<0.05\right)$. Multiple comparisons tests indicated that the potentiation was significantly smaller in slices from KO mice at 15, 30, and 60 min after TBS ( $p<0.01$; Newman-Keuls tests).

Field potential responses to the patterned bursts (TBS) are shown in Figure 7. Responses to the first burst consist of four distinct fEPSPs, decreasing in amplitude and followed by a small, prolonged negative potential. In later bursts, the initial fEPSP was typically smaller than that in the first burst, and the second, third, and fourth fEPSPs were more variable; however, all of the fEPSPs in later burst responses were typically broader that those in the first burst response. There were no clear differences in these response patterns in slices from WT and $\mathrm{KO}$ mice. Burst responses were quantified by calculating the area of negativity underlying the $75 \mathrm{~ms}$ period after the first stimulus of each burst. There were no differences in total area of the first burst between $\mathrm{KO}$ and WT slices either at $3-6$ months of age $\left(t_{(20)}=0.19 ; p>0.8\right)$ or at $6-12$ months of age $\left(t_{(36)}=0.99 ; p>0.3\right)$. ANOVA on the normalized burst area did not yield any significant main effects attributable to genotype (3-6 months of age, $F_{(1,20)}=0.05, p>0.8 ; 6-12$ months of age, $\left.F_{(1,36)}=0.03, p>0.8\right)$ nor any interactions between genotype and burst number (3-6 months of age, $F_{(8,160)}=$ $1.76, p>0.05 ; 6-12$ months of age, $\left.F_{(8,288)}=0.32, p>0.9\right)$.

\section{Hippocampal field CA1}

Several previous reports that LTP is normal in field CA1 of FMRP-deficient mice (Godfraind et al., 1996; Paradee et al., 1999; Li et al., 2002) all tested mice younger than 6 months of age. Because our observations in APC indicate that an LTP deficit can be age dependent, we examined field CA1 of hippocampus from WT and KO mice at 3-6 months and 6-12 months of age.

\section{Input-output curves and paired-pulse plasticity}

Input-output curves were generated for SC-evoked fEPSPs in one slice from each animal. The results are shown in Figure $8 \mathrm{~A}$. Genotype had no significant main effects on input-output curves at $3-6$ months $\left(F_{(1,38)}=1.33 ; p>0.2\right)$ or $6-12$ months $\left(F_{(1,21)}=\right.$ $1.84 ; p>0.1)$ of age; there were no interactions between genotype and stimulus intensity on response size in either age group (3-6 months of age, $F_{(7,266)}=1.02, p>0.4 ; 6-12$ months of age, $\left.F_{(7,147)}=1.64, p>0.1\right)$.

Paired-pulse stimulation at IPIs of 50-800 ms produced facilitation at SC synapses in CA1 (Fig. 8 B). There were no significant main effects of genotype on facilitation at either 3-6 months $\left(F_{(1,38)}=2.30 ; p>0.1\right)$ or $6-12$ months $\left(F_{(1,21)}=0.17\right.$; $p>0.6)$ of age. Nor were there significant interactions between genotype and IPI in either age group (3-6 months of age, $F_{(5,190)}=0.73, p>0.5 ; 6-12$ months of age, $F_{(5,105)}=0.38, p>$ $0.8)$.

\section{LTP induced by TBS}

In mice aged 3-6 months, TBS induced a large initial potentiation of the fEPSP that decayed within $\sim 10$ min to a stable level that remained constant for the duration of recording. Similar amounts of potentiation were observed in both WT and KO mice
A INPUT-OUTPUT CURVES
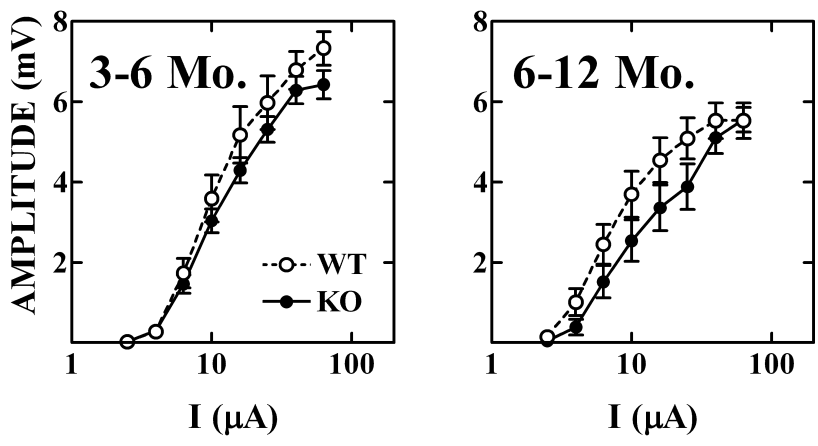

B PAIRED-PULSE FACILITATION
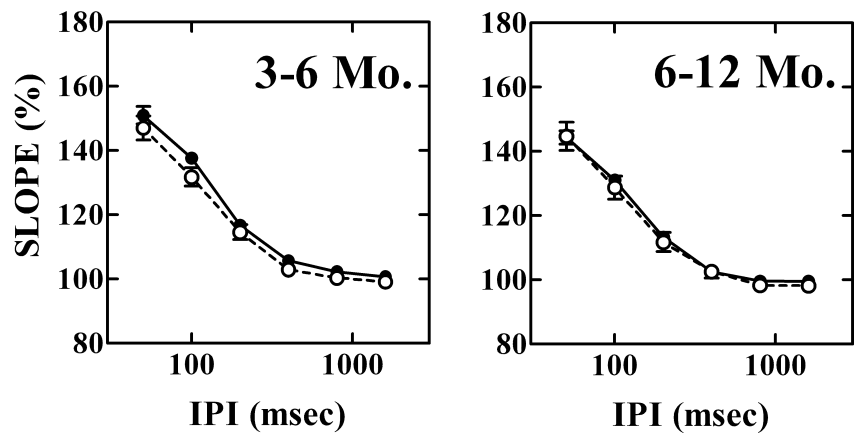

Figure 8. Synaptic input- output curves and paired-pulse facilitation in hippocampal field CA1 of WT and Fmr 1 KO mice. $A$, Input- output curves for SC-evoked fEPSP amplitude in slices from $18 \mathrm{WT}$ and $22 \mathrm{KO}$ mice aged $3-6$ months and nine WT and $14 \mathrm{KO}$ mice aged $6-12$ months (means \pm SEM). $\boldsymbol{B}$, Paired-pulse facilitation curves for the same slices in $\boldsymbol{A}$ (means \pm SEM). Mo., Months.

after either a five-burst TBS (Fig. 9A,B) or a 10-burst TBS (Fig. $9 C, D)$. There were no significant main effects of genotype on potentiation after either five bursts $\left(F_{(1,22)}=1.47 ; p>0.2\right)$ or 10 bursts $\left(F_{(1,26)}=0.44 ; p>0.5\right)$. There were also no significant interactions between genotype and time after TBS (five bursts, $F_{(3,66)}=0.46, p>0.7 ; 10$ bursts, $\left.F_{(3,78)}=0.47, p>0.6\right)$.

Very similar results were obtained in slices from mice aged 6-12 months (Fig. 10). ANOVA indicated no main effect of genotype on potentiation after TBS consisting of five $\left(F_{(1,31)}=0.09\right.$; $p>0.7)$ or $10\left(F_{(1,37)}=3.50 ; p=0.07\right)$ bursts, although the KO mice tended to show slightly less potentiation in the latter case (particularly right after TBS). The interactions between genotype and time after TBS were not significant (five bursts, $F_{(3,93)}=0.03$, $p>0.9 ; 10$ bursts, $\left.F_{(3,111)}=1.63, p>0.1\right)$.

Not surprisingly, analysis of the burst responses did not reveal any significant differences between slices from WT and KO mice. For synapses receiving a 10-burst TBS (Fig. 11), the area of the first burst response was no different in slices from WT and KO mice at either $3-6$ months $\left(t_{(53)}=0.78 ; p>0.4\right)$ or $6-12$ months $\left(t_{(46)}=1.36 ; p>0.15\right)$ of age. The normalized area of the subsequent bursts also did not show a main effect of genotype (3-6 months of age, $F_{(1,53)}=2.34, p>0.1 ; 6-12$ months of age, $\left.F_{(1,46)}=0.34, p>0.55\right)$ nor an interaction of genotype with burst number $\left(3-6\right.$ months of age, $F_{(8,424)}=0.24, p>0.95 ; 6-12$ months of age, $\left.F_{(8,368)}=1.79, p>0.05\right)$.

Similarly, for synapses receiving a five-burst TBS (Fig. 12), the area of the first burst response was not significantly different in slices from WT and KO mice at either 3-6 months $\left(t_{(40)}=0.45\right.$; 
$p>0.65)$ or $6-12$ months $\left(t_{(43)}=1.86\right.$; $p=0.07)$ of age. Subsequent burst responses (normalized) also did not show a main effect of genotype (3-6 months of age, $F_{(1,40)}=0.19, p>0.65 ; 6-12$ months of age, $\left.F_{(1,43)}=0.74, p>0.35\right)$ nor an interaction of genotype with burst number $\left(3-6\right.$ months of age, $F_{(3,120)}=0.71$, $p>0.5 ; 6-12$ months of age, $F_{(3,129)}=$ $0.46, p>0.7)$.

\section{Discussion}

Although the Fmr1 knock-out mouse does not exactly mimic the genetic abnormality of FXS at the molecular level, the mouse model and human syndrome share the fundamental common end point of a lack of expression of a single gene product throughout the lifespan. Because the definitive phenotypic characteristic of FXS is mental retardation, understanding the neurobiological consequences of silencing the Fmrl gene in mice is of paramount importance for exploiting the mouse model to test therapeutic strategies. The Fmrl gene encodes a protein (FMRP) that contains RNA binding domains and both nuclear localization and nuclear export signal sequences (Bardoni et al., 2001). In brain, FMRP is seen in cytoplasm both in neuronal somata and dendrites (Devys et al., 1993; Feng et al., 1997). FMRP forms complexes with other proteins, including two FMRP homologs, the fragile X-related proteins 1 and 2 (FXR1P and FXR2P), along with mRNA in association with ribosomes (Eberhart et al., 1996; Khandjian et al., 1996; Corbin et al., 1997; Feng et al., 1997; Ceman et al., 1999). In in vitro experiments, binding of FMRP to RNA appears to inhibit translation (Laggerbauer et al., 2001; Li et al., 2001).

The primitive appearance of dendritic spines in FXS brains (Irwin et al., 2001) and brains of FMRP-deficient mice (Irwin et al., 2002) suggest that FMRP participates in spine maturation or plasticity (Greenough et al., 2001). Activation of metabotropic glutamate receptors (mGluRs) in cellular fractions enriched in dendritic spines triggers protein synthetic activity most likely via translation of dendritic resident mRNA associated with polyribosomes (Weiler et al., 1997). This activity is severely blunted in Fmr1 KO mice, suggesting that FMRP plays an important role in regulation of dendritic protein synthesis (Weiler et al., 2004). Levels of FMRP are regulated by synaptic activity in cultured neurons (Antar et al., 2004) and by experience in intact animals (Todd and Mack, 2000; Irwin et al., 2000, 2005; Todd et al., 2003; Gabel et al., 2004) and involve both mGluR- and NMDA receptor-dependent
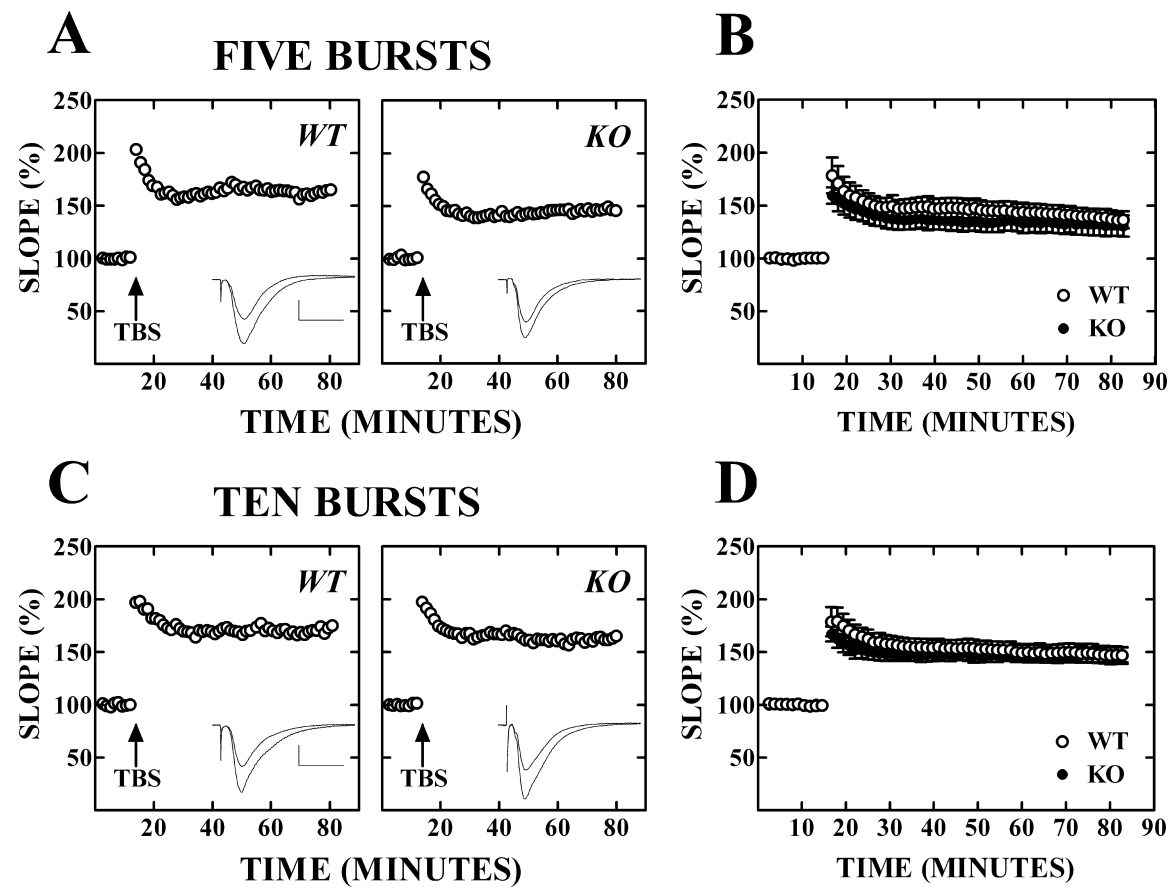

Figure 9. LTP after 5- or 10-burst TBS in hippocampal field CA1 of slices from 3- to 6-month-old K0 and WT mice. A, Representative experiments from a 4.5-month-old WT mouse and a 5.5-month-old KO mouse with five-burst TBS. The insets show field EPSP records taken immediately before and $60 \mathrm{~min}$ after TBS. Each waveform is an average of four consecutive responses. Calibration: $1 \mathrm{mV}, 10 \mathrm{~ms} . \boldsymbol{B}$, Average (mean \pm SEM) results from $11 \mathrm{WT}$ slices and $12 \mathrm{~K} 0$ slices. C, Representative experiments from a 4.5-month-old WT mouse and a 3-month-old K0 mouse with 10-burst TBS. The insets show field EPSP records taken immediately before and $60 \mathrm{~min}$ after TBS. Each waveform is an average of four consecutive responses. Calibration: $1 \mathrm{mV}, 10 \mathrm{~ms}$. D, Average (mean \pm SEM) results from 15 WT slices and $13 \mathrm{KO}$ slices.
A

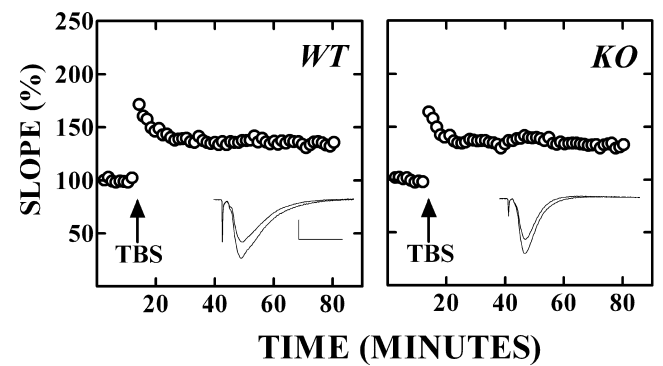

C

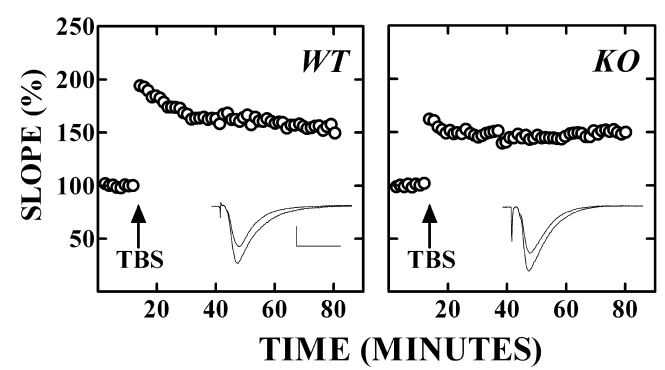

B

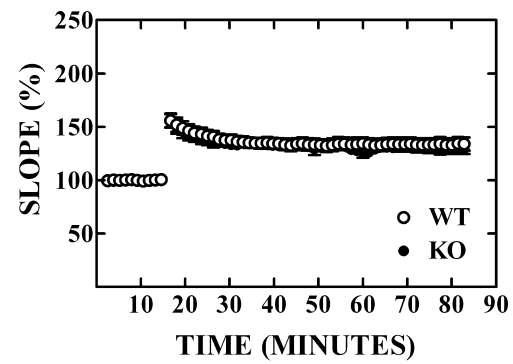

D

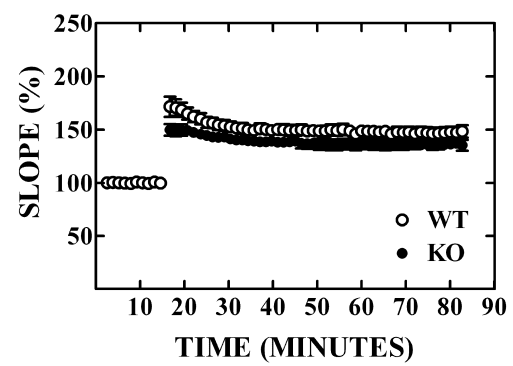

Figure 10. LTP after 5- or 10-burst TBS in hippocampal field CA1 of slices from 6- to 12-month-old K0 and WT mice. $A$, Representative experiments from an 8-month-old WT mouse and an 8-month-old K0 mouse with five-burst TBS. The insets show field EPSP records taken immediately before and $60 \mathrm{~min}$ after TBS. Each waveform is an average of four consecutive responses. Calibration: $1 \mathrm{mV}, 10 \mathrm{~ms}$. B, Average (mean \pm SEM) results from 15 WT slices and $18 \mathrm{~K} 0$ slices. $C$, Representative experiments from an 8-month-old WT mouse and a 6.5-month-old KO mouse with 10-burst TBS. The insets show field EPSP records taken immediately before and $60 \mathrm{~min}$ after TBS. Each waveform is an average of four consecutive responses. Calibration: $1 \mathrm{mV}, 10 \mathrm{~ms}$. D, Average (mean \pm SEM) results from 15 WT slices and $24 \mathrm{KO}$ slices. 

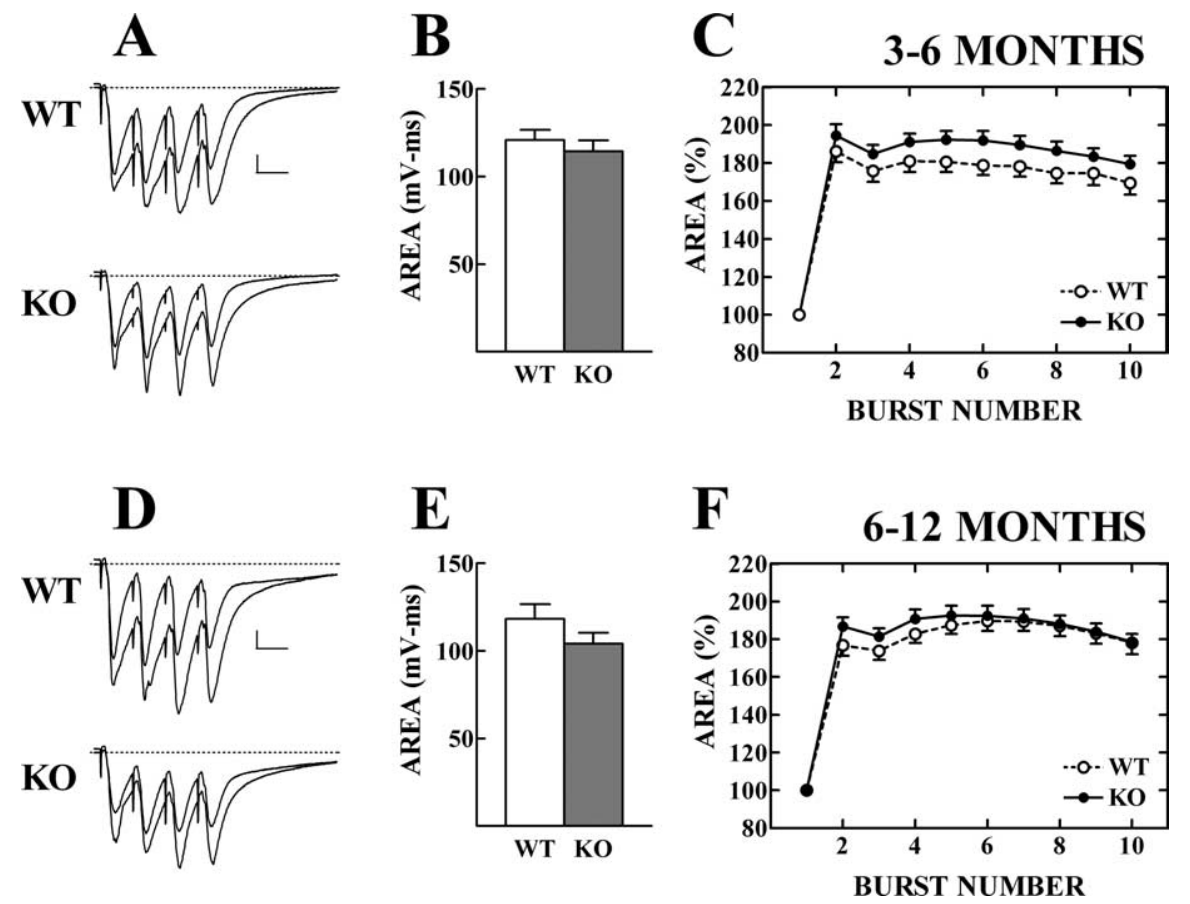

Figure 11. Burst responses recorded in CA1 in response to 10-burst TBS. $A$, Records of first and second burst response in a 3-month-old WT and a 4-month-old KO mouse. The second burst elicits the larger response. Calibration: $1 \mathrm{mV}, 10 \mathrm{~ms}$. B, Average (mean + SEM) area of negativity underlying first burst response in $26 \mathrm{WT}$ and $23 \mathrm{~K} 0$ slices from mice aged $3-6$ months. C, Average (mean \pm SEM) area of each burst response normalized to the area of the first burst in each slice from 26 WT and $23 \mathrm{~K} 0$ mice aged 3-6 months. D, As in $\boldsymbol{A}$ for 8-month-old WT and K0 mice. $\boldsymbol{E}, \boldsymbol{F}, \mathrm{As}$ in $\boldsymbol{B}$ and $\boldsymbol{C}$ for 16 WT and $31 \mathrm{KO}$ mice aged $6-12$ months. pathways. These findings indicate that sensory stimulation or synaptic activity can alter levels and localization of FMRP in postsynaptic neurons and modulate local protein synthesis.

We used slice preparations and electrophysiological methods to investigate synaptic function and plasticity in Fmrl KO mice and WT controls. We observed a pronounced deficit in expression of stable LTP in ASSN synapses in the anterior piriform cortex in mice lacking FMRP. This deficit only appeared in tissue from animals at least 6 months of age and was not observed in slices from hippocampus. We did not see significant differences in basal synaptic transmission, alterations in paired-pulse plasticity, or significantly modified local circuit properties in responses to highfrequency bursts. The same age-dependent LTP impairment in the APC was observed whether or not $\mathrm{GABA}_{\mathrm{A}}$ receptors were blocked. These findings suggest that the primary defect in LTP in the olfactory cortex involves mechanisms responsible for stabilization of potentiation. Both the age dependence and regional selectivity of the defect place constraints on the cellular basis for it.

FMRP could participate directly in the stabilization of LTP. Because LTP is normal in the hippocampus, the present results suggest that piriform and hippocampal synapses differ either in an obligatory step requiring FMRP or in the degree to which other proteins can compensate for FMRP deficiency. FXR1P and FXR2P are thought to associate with FMRP in messenger ribonucleoproteins to regulate translation of mRNAs (Ceman et al., 1999) and possibly could compensate for FMRP.

One significant difference between piriform and hippocampal LTP is kinetic: hippocampal LTP develops fully within $30-60 \mathrm{~s}$ after induction (Gustafsson et al., 1989), whereas piriform LTP develops more slowly (Jung et al., 1990a). LTP in sensorimotor cortex, impaired in FMRP-deficient mice, also shows a protracted development period (Li et al., 2002). A second difference between piriform ASSN synapses and hippocampal CA1 synapses is their paired-pulse characteristics. CA1 synapses exhibit facilitation (Creager et al., 1980), whereas piriform ASSN synapses exhibit depression (Bower and Haberly, 1986). The mechanism responsible and significance of these differences are not clear. Nevertheless, they represent a potential synaptic correlate of the LTP differences.

mGluR-dependent long-term depression (LTD) is altered in hippocampus of Fmr1 KO mice (Huber et al., 2002). Because mice lacking FMRP exhibited enhanced LTD, it was suggested that FMRP may normally inhibit LTD by suppressing mGluRstimulated translation of dendritic mRNAs encoding proteins involved in synaptic turnover (Huber et al., 2002).

At the molecular level, it has been suggested that FMRP may exercise several neuronal functions including export of mRNAs from nucleus to cytosol, transport of mRNAs into dendrites, and repression of mRNA translation (Antar and Bassell, 2003). mRNA binding partners of FMRP have been identified, including messages for cytoskeletal proteins and signal transduction elements that could participate in spine/synaptic plasticity (Brown et al., 2001; Darnell et al., 2001; Miyashiro et al., 2003).
Figure 12. Burst responses recorded in CA1 in response to five-burst TBS. $A$, Mean + SEM area for first burst responses in 20 slices from 3- to 6-month-old WT mice and 18 slices from 3to 6 -month-old KO mice. $B$, Area (mean \pm SEM) of all five bursts normalized to the first burst area in each slice. $\boldsymbol{C}, \boldsymbol{D}$, As in $\boldsymbol{A}$ and $\boldsymbol{B}$ for $18 \mathrm{WT}$ and $26 \mathrm{KO}$ mice aged $6-12$ months. 
As an alternative to direct participation of FMRP in LTP, absence of the protein in Fmrl KO mice might indirectly create a condition suppressing synaptic plasticity by altering the localization or abundance of other molecules that control LTP expression or stabilization. The dendritic localization of some (Miyashiro et al., 2003), but not all (Steward et al., 1998), dendritic resident mRNAs is altered in Fmr1 KO mice. Importantly, Li and colleagues (2002) observed reduced expression of AMPA receptor subunit GluR1 selectively in neocortex but not hippocampus of Fmr1 KO mice. Because suppressing expression of GluR1 can inhibit expression of stable LTP (Vanderklish et al., 1992; Zamanillo et al., 1999), this provides one mechanism by which absence of FMRP could indirectly reduce LTP. It should be noted, however, that a recent study did not find decreased expression of GluR1 in visual cortex of Fmr1 KO mice (Restivo et al., 2005); whether GluR1 subunits are altered in piriform cortex remains to be determined.

The age dependence of the LTP deficit in olfactory cortex is somewhat surprising because FXS is a developmental disorder with cognitive symptoms typically appearing within the first 2 postnatal years (Hagerman, 2002). The LTP deficit did not appear until well into adulthood in $\mathrm{KO}$ mice. The present results do not provide insight into mechanisms responsible for early effects on cognitive development. They might, however, explain difficulty in acquiring particular cognitive skills that develop later in adolescence, if such skills require or use the same mechanisms involved in LTP in specific cortical areas.

The cause of the age-dependent impairment of LTP in the anterior piriform cortex is presently unclear. As noted above, one consequence of FMRP deficiency is abnormal spine maturation. Spine development has been most studied in somatosensory cortex of mice, and the pattern of changes is complex. KO-WT differences in spine shape are robust at postnatal weeks $1-2$, become minimal at 1 month of age, and re-emerge by young adulthood (2-3 months of age) (Nimchinsky et al., 2001; Galvez and Greenough, 2005). Whether these differences are maintained or exaggerated with advancing age in mice is unknown; however, the human studies indicate that spine abnormalities in FXS persist into middle age (Irwin et al., 2001). The morphological signs could very well reflect functional deficiencies in these postsynaptic elements. It will be important to determine the influence of age on spine shape in APC in Fmr1 KO and WT mice.

LTP shows age-related changes in hippocampus; these involve deficits in induction rather than expression mechanisms, with most reports documenting changes only in senescent animals (Barnes, 1979; Rosenzweig et al., 1997). However, a recent study demonstrated deficits in LTP in rats as young as 7-10 months of age (Rex et al., 2005), comparable with the age-dependent LTP deficiency found here. Those investigators found that LTP stability was impaired specifically in CA1 basal dendritic synapses, whereas LTP remained normal in apical dendritic synapses on the same neurons. Pharmacological studies suggested that basal dendritic LTP fails to stabilize in middle-aged rats because of altered adenosine release during TBS (Rex et al., 2005). How these results relate to FMRP is presently unclear, but it will be of interest to test for LTP in these synapses in the Fmr1 KO mice.

Behavioral studies have not revealed striking learning/memory deficits in Fmr1 KO mice. There are several potential explanations for this. First, most of the emphasis has been placed on hippocampal-dependent tasks; perhaps hippocampal function is neither impaired nor important for the cognitive functions compromised in FXS. Second, compensatory proteins or mechanisms may be more readily available for mice than for humans. Third, the behavioral abilities tested in mice may not map to the cogni- tive domains most affected in FXS. It has been proposed that olfactory-guided tasks may be the most appropriate for assessing human-like cognitive functions in rodents (Slotnick and Katz, 1974; Staubli et al., 1987; Bunsey and Eichenbaum, 1996). The selective impairment in LTP we have observed in the anterior piriform cortex of Fmr1 KO mice suggests that tests using olfactory cues may be particularly useful for assessing learning and memory abilities in these mice. Fourth, few studies have examined behavioral or neural phenotypes in $\mathrm{KO}$ mice beyond 3 months of age. The findings reported here suggest that more profound cognitive deficits may be expected as FMRP-deficient mice mature and age.

\section{References}

Antar LN, Bassell GJ (2003) Sunrise at the synapse: the FMRP mRNP shaping the synaptic interface. Neuron 37:555-558.

Antar LN, Afroz R, Dictenberg JB, Carroll RC, Bassell GJ (2004) Metabotropic glutamate receptor activation regulates fragile $\mathrm{X}$ mental retardation protein and FMR1 mRNA localization differentially in dendrites and at synapses. J Neurosci 24:2648-2655.

Bagni C, Greenough WT (2005) From mRNP trafficking to spine dysmorphogenesis: the roots of fragile X syndrome. Nat Rev Neurosci 6:376-387.

Bakker CE, Verheij C, Willemsen R, van der Helm R, Oerlemans F, Vermey M, Bygrave A, Hoogeveen AT, Oostra BA, Reyniers E, De Boulle K, D'Hooge R, Cras P, van Velzen D, Nagels D, Martin JJ, De Deyn PP, Darby JK, Willems PJ (1994) Fmr1 knockout mice: a model to study fragile X mental retardation. Cell 78:23-33.

Bardoni B, Schenck A, Mandel JL (2001) The fragile X mental retardation protein. Brain Res Bull 56:375-382.

Barnes CA (1979) Memory deficits associated with senescence: a neurophysiological and behavioral study in the rat. J Comp Physiol Psychol 93:74-104.

Bower JM, Haberly LB (1986) Facilitating and nonfacilitating synapses on pyramidal cells: a correlation between physiology and morphology. Proc Natl Acad Sci USA 83:1115-1119.

Brown V, Jin P, Ceman S, Darnell JC, O’Donnell WT, Tenenbaum SA, Jin X, Feng Y, Wilkinson KD, Keene JD, Darnell RB, Warren ST (2001) Microarray identification of FMRP-associated brain mRNAs and altered mRNA translational profiles in fragile X syndrome. Cell 107:477-487.

Bunsey M, Eichenbaum H (1996) Conservation of hippocampal memory function in rats and humans. Nature 379:255-257.

Ceman S, Brown V, Warren ST (1999) Isolation of an FMRP-associated messenger ribonucleoprotein particle and identification of nucleolin and the fragile X-related proteins as components of the complex. Mol Cell Biol 19:7925-7932.

Collins GG (1994) The characteristics and pharmacology of olfactory cortical LTP induced by theta-burst high frequency stimulation and $1 S, 3 R$ ACPD. Neuropharmacology 33:87-95.

Comery TA, Harris JB, Willems PJ, Oostra BA, Irwin SA, Weiler IJ, Greenough WT (1997) Abnormal dendritic spines in fragile X knockout mice: maturation and pruning deficits. Proc Natl Acad Sci USA 94:5401-5404.

Corbin F, Bouillon M, Fortin A, Morin S, Rousseau F, Khandjian EW (1997) The fragile $\mathrm{X}$ mental retardation protein is associated with poly $(\mathrm{A})+$ mRNA in actively translating polyribosomes. Hum Mol Genet 6:1465-1472.

Creager R, Dunwiddie T, Lynch G (1980) Paired-pulse and frequency facilitation in the CA1 region of the in vitro rat hippocampus. J Physiol (Lond) 299:409-424.

Darnell JC, Jensen KB, Jin P, Brown V, Warren ST, Darnell RB (2001) Fragile X mental retardation protein targets $\mathrm{G}$ quartet mRNAs important for neuronal function. Cell 107:489-499.

de Vries BB, Halley DJ, Oostra BA, Niermeijer MF (1998) The fragile X syndrome. J Med Genet 35:579-589.

Devys D, Lutz Y, Rouyer N, Bellocq JP, Mandel JL (1993) The FMR-1 protein is cytoplasmic, most abundant in neurons and appears normal in carriers of a fragile X premutation. Nat Genet 4:335-340.

Eberhart DE, Malter HE, Feng Y, Warren ST (1996) The fragile X mental retardation protein is a ribonucleoprotein containing both nuclear localization and nuclear export signals. Hum Mol Genet 5:1083-1091.

Feng Y, Gutekunst CA, Eberhart DE, Yi H, Warren ST, Hersch SM (1997) Fragile $\mathrm{X}$ mental retardation protein: nucleocytoplasmic shuttling and association with somatodendritic ribosomes. J Neurosci 17:1539-1547. 
Gabel LA, Won S, Kawai H, McKinney M, Tartakoff AM, Fallon JR (2004) Visual experience regulates transient expression and dendritic localization of fragile X mental retardation protein. J Neurosci 24:10579-10583.

Galvez R, Greenough WT (2005) Sequence of abnormal dendritic spine development in primary somatosensory cortex of a mouse model of the fragile X mental retardation syndrome. Am J Med Genet A 135:155-160.

Godfraind JM, Reyniers E, De Boulle K, D’Hooge R, De Deyn PP, Bakker CE, Oostra BA, Kooy RF, Willems PJ (1996) Long-term potentiation in the hippocampus of fragile X knockout mice. Am J Med Genet 64:246-251.

Greenough WT, Klintsova AY, Irwin SA, Galvez R, Bates KE, Weiler IJ (2001) Synaptic regulation of protein synthesis and the fragile $\mathrm{X}$ protein. Proc Natl Acad Sci USA 98:7101-7106.

Gustafsson B, Asztely F, Hanse E, Wigstrom H (1989) Onset characteristics of long-term potentiation in the guinea-pig hippocampal CA1 region in vitro. Eur J Neurosci 1:382-394.

Hagerman RJ (2002) Medical follow-up and pharmacotherapy. In: Fragile $\mathrm{X}$ syndrome: diagnosis, treatment, and research (Hagerman RJ, Hagerman PJ, eds), pp 287-338. Baltimore: Johns Hopkins UP.

Huber KM, Gallagher SM, Warren ST, Bear MF (2002) Altered synaptic plasticity in a mouse model of fragile $\mathrm{X}$ mental retardation. Proc Natl Acad Sci USA 99:7746-7750.

Irwin SA, Swain RA, Christmon CA, Chakravarti A, Weiler IJ, Greenough WT (2000) Evidence for altered fragile-X mental retardation protein expression in response to behavioral stimulation. Neurobiol Learn Mem 74:87-93.

Irwin SA, Patel B, Idupulapati M, Harris JB, Crisostomo RA, Larsen BP, Kooy F, Willems PJ, Cras P, Kozlowski PB, Swain RA, Weiler IJ, Greenough WT (2001) Abnormal dendritic spine characteristics in the temporal and visual cortices of patients with fragile-X syndrome: a quantitative examination. Am J Med Genet 98:161-167.

Irwin SA, Idupulapati M, Gilbert ME, Harris JB, Chakravarti AB, Rogers EJ, Crisostomo RA, Larsen BP, Mehta A, Alcantara CJ, Patel B, Swain RA, Weiler IJ, Oostra BA, Greenough WT (2002) Dendritic spine and dendritic field characteristics of layer $\mathrm{V}$ pyramidal neurons in the visual cortex of fragile-X knockout mice. Am J Med Genet 111:140-146.

Irwin SA, Christmon CA, Grossman AW, Galvez R, Kim SH, DeGrush BJ, Weiler IJ, Greenough WT (2005) Fragile X mental retardation protein levels increase following complex environment exposure in rat brain regions undergoing active synaptogenesis. Neurobiol Learn Mem 83:180-187.

Jung MW, Larson J (1994) Further characteristics of long-term potentiation in piriform cortex. Synapse 18:298-306.

Jung MW, Larson J, Lynch G (1990a) Long-term potentiation of monosynaptic EPSPs in rat piriform cortex in vitro. Synapse 6:279-283.

Jung MW, Larson J, Lynch G (1990b) Role of NMDA and non-NMDA receptors in synaptic transmission in rat piriform cortex. Exp Brain Res 82:451-455.

Kanter ED, Haberly LB (1990) NMDA-dependent induction of long-term potentiation in afferent and association fiber systems of piriform cortex in vitro. Brain Res 525:175-179.

Kanter ED, Haberly LB (1993) Associative long-term potentiation in piriform cortex slices requires GABA A blockade. J Neurosci 13:2477-2482.

Khandjian EW, Corbin F, Woerly S, Rousseau F (1996) The fragile X mental retardation protein is associated with ribosomes. Nat Genet 12:91-93.

Kooy RF (2003) Of mice and the fragile X syndrome. Trends Genet 19:148-154.

Laggerbauer B, Ostareck D, Keidel EM, Ostareck-Lederer A, Fischer U (2001) Evidence that fragile $\mathrm{X}$ mental retardation protein is a negative regulator of translation. Hum Mol Genet 10:329-338.

Larson J, Lynch G (1988) Role of N-methyl-D-aspartate receptors in the induction of synaptic potentiation by burst stimulation patterned after the hippocampal theta-rhythm. Brain Res 441:111-118.

Larson J, Wong D, Lynch G (1986) Patterned stimulation at the theta frequency is optimal for the induction of hippocampal long-term potentiation. Brain Res 368:347-350.

Larson J, Lynch G, Games D, Seubert P (1999) Alterations in synaptic transmission and long-term potentiation in hippocampal slices from young and aged PDAPP mice. Brain Res 840:23-35.
Li J, Pelletier MR, Perez Velazquez JL, Carlen PL (2002) Reduced cortical synaptic plasticity and GluR1 expression associated with fragile X mental retardation protein deficiency. Mol Cell Neurosci 19:138-151.

Li Z, Zhang Y, Ku L, Wilkinson KD, Warren ST, Feng Y (2001) The fragile X mental retardation protein inhibits translation via interacting with mRNA. Nucleic Acids Res 29:2276-2283.

Miyashiro KY, Beckel-Mitchener A, Purk TP, Becker KG, Barret T, Liu L, Carbonetto S, Weiler IJ, Greenough WT, Eberwine J (2003) RNA cargoes associating with FMRP reveal deficits in cellular functioning in Fmr1 null mice. Neuron 37:417-431.

Nimchinsky EA, Oberlander AM, Svoboda K (2001) Abnormal development of dendritic spines in FMR1 knock-out mice. J Neurosci 21:5139-5146.

O’Donnell WT, Warren ST (2002) A decade of molecular studies of fragile X syndrome. Annu Rev Neurosci 25:315-338.

Paradee W, Melikian HE, Rasmussen DL, Kenneson A, Conn PJ, Warren ST (1999) Fragile X mouse: strain effects of knockout phenotype and evidence suggesting deficient amygdala function. Neuroscience 94:185-192.

Restivo L, Ferrari F, Passino E, Sgobio C, Bock J, Oostra BA, Bagni C, Ammassari-Teule M (2005) Enriched environment promotes behavioral and morphological recovery in a mouse model for the fragile $\mathrm{X}$ syndrome. Proc Natl Acad Sci USA 102:11557-11562.

Rex CS, Kramar EA, Colgin LL, Lin B, Gall CM, Lynch G (2005) Long-term potentiation is impaired in middle-aged rats: regional specificity and reversal by adenosine receptor antagonists. J Neurosci 25:5956-5966.

Rosenzweig ES, Rao G, McNaughton BL, Barnes CA (1997) Role of temporal summation in age-related long-term potentiation-induction deficits. Hippocampus 7:549-558.

Schapiro MB, Murphy DG, Hagerman RJ, Azari NP, Alexander GE, Miezejeski CM, Hinton VJ, Horwitz B, Haxby JV, Kumar A (1995) Adult fragile X syndrome: neuropsychology, brain anatomy, and metabolism. Am J Med Genet 60:480-493.

Slotnick BM, Katz HM (1974) Olfactory learning-set formation in rats. Science 185:796-798.

Staubli U, Fraser D, Faraday R, Lynch G (1987) Olfaction and the "data" memory system in rats. Behav Neurosci 101:757-765.

Steward O, Bakker CE, Willems PJ, Oostra BA (1998) No evidence for disruption of normal patterns of mRNA localization in dendrites or dendritic transport of recently synthesized mRNA in FMR1 knockout mice, a model for human fragile-X mental retardation syndrome. NeuroReport 9:477-481.

Todd PK, Mack KJ (2000) Sensory stimulation increases cortical expression of the fragile X mental retardation protein in vivo. Brain Res Mol Brain Res 80:17-25.

Todd PK, Malter JS, Mack KJ (2003) Whisker stimulation-dependent translation of FMRP in the barrel cortex requires activation of type I metabotropic glutamate receptors. Brain Res Mol Brain Res 110:267-278.

Vanderklish P, Neve R, Bahr BA, Arai A, Hennegriff M, Larson J, Lynch G (1992) Translational suppression of a glutamate receptor subunit impairs long-term potentiation. Synapse 12:333-337.

Weiler IJ, Irwin SA, Klintsova AY, Spencer CM, Brazelton AD, Miyashiro K, Comery TA, Patel B, Eberwine J, Greenough WT (1997) Fragile X mental retardation protein is translated near synapses in response to neurotransmitter activation. Proc Natl Acad Sci USA 94:5395-5400.

Weiler IJ, Spangler CC, Klintsova AY, Grossman AW, Kim SH, BertainaAnglade V, Khaliq H, de Vries FE, Lambers FA, Hatia F, Base CK, Greenough WT (2004) Fragile X mental retardation protein is necessary for neurotransmitter-activated protein translation at synapses. Proc Natl Acad Sci USA 101:17504-17509.

Willemsen R, Oostra BA, Bassell GJ, Dictenberg J (2004) The fragile X syndrome: from molecular genetics to neurobiology. Ment Retard Dev Disabil Res Rev 10:60-67.

Zamanillo D, Sprengel R, Hvalby O, Jensen V, Burnashev N, Rozov A, Kaiser KM, Koster HJ, Borchardt T, Worley P, Lubke J, Frotscher M, Kelly PH, Sommer B, Andersen P, Seeburg PH, Sakmann B (1999) Importance of AMPA receptors for hippocampal synaptic plasticity but not for spatial learning. Science 284:1805-1811. 